\title{
PENGARUH PEMBERIAN FRAKSI SEMIPOLAR HERBA PUTRI MALU (Mimosa pudica Linn) TERHADAP PENURUNAN KADAR GLUKOSA DARAH PADA MENCIT YANG DIINDUKSI ALOKSAN
}

\author{
Devy Purnama Sari ${ }^{1}$; Fakhruddin ${ }^{2}$; Yogie $\operatorname{Irawan}^{3}$ \\ ${ }^{1,2,3}$ STIKes Borneo Cendekia Medika Pangkalan Bun \\ ${ }^{1}$ Email:prnmdv487@gmail.com
}

\begin{abstract}
ABSTRAK
Pendahuluan: Hiperglikemia merupakan peningkatan kadar glukosa dalam darah yang diakibatkan karena tubuh tidak dapat menghasilkan insulin atau tidak dapat menggunakan insulin secara efektif. Penelitian ini bertujuan untuk mengetahui pengaruh pemberian fraksi semipolar herba putri malu (Mimosa pudica Linn) terhadap penurunan kadar gula darah pada mencit yang diinduksi aloksan.

Metode: Hewan uji yang digunakan sebanyak 18 ekor dan dibagi menjadi 6 kelompok yaitu kontrol negatif ( $\mathrm{Na} \mathrm{CMC} \mathrm{0,5 \% ),} \mathrm{kontrol} \mathrm{positif} \mathrm{(glibenklamid}$ $0,65 \mathrm{mg} / \mathrm{kgBB}$ ), Kelompok perlakuan I dan II ekstrak etanol herba putri malu dosis; 2,5 gr/kgBB dan $5 \mathrm{gr} / \mathrm{kgBB}$, Kelompok perlakuan III dan IV fraksi semipolar herba putri malu dosis; $0,7 \mathrm{gr} / \mathrm{kgBB}$ dan $13 \mathrm{gr} / \mathrm{kgBB}$.

Hasil: Analisa data menggunakan uji ANOVA menyatakan signifikasi $p<0,05$. Hasil penelitian ini menunjukkan bahwa fraksi semipolar herba putri malu (Mimosa pudica Linn) dapat menurunkan kadar gula darah sebanding dengan kontrol positif. Kemudian pada uji LSD menyatakan kelompok perlakuan IV dengan nilai sig 0,915 memiliki kemampuan paling baik diantara kelompok perlakuan lain (I,II, \& III).

Kesimpulan: Terdapat pengaruh pemberian fraksi semipolar herba putri malu (Mimosa pudica Linn) terhadap penurunan kadar gula darah mencit yang diinduksi aloksan.
\end{abstract}

Kata Kunci: Fraksi, Herba Putri Malu, Aloksan, Diabetes Melitus

\section{ABSTRACT}

Introduction: Hyperglycemia is an increasedin the blood glucose levels resulting from the body that unable to produce insulin or to use insulin effectively. This study aimed to determine the effect of giving semipolar fraction of the mimosa herb (Mimosa pudica Linn) in reducing the blood glucose levels in alloxaninduced induced white mice.

Method: The study used eighteen mice divided into six groups. Those groups are negative control ( $\mathrm{Na} \mathrm{CMC} 0,5 \%$ ), positive control (glibenklamid0,65 mg/kgBB), treatment groups I and II that given an ethanol extract of mimosa herb (2,5 $\mathrm{gr} / \mathrm{kgBB}, 5 \mathrm{gr} / \mathrm{kgBB}$ ), and treatment groups III and IV that given semipolar fraction of mimosa herb $(0,7 \mathrm{gr} / \mathrm{kgBB}$ and $13 \mathrm{gr} / \mathrm{kgBB})$

Results: The results of analyzing data used ANOVA Test showed that semipolar fraction of mimosa herb can reduce the blood glucose level comparable to positive control group withp $<0.05$. Then, LSD test showed that treatment group IV with a sig value 0,915 had the best ability among treatment groups (I,II, \& III) 
Conclusion: It can be concluded that there is an effect of giving the semipolar fraction of mimosa herb in reducing the blood glucose level in alloxan-induced white mice.

Key words: fraction, Mimosa Herb, Alloxan, Diabetes Mellitus

\section{PENDAHULUAN}

Dalam perkembangannya penyakit degeneratif telah menjadi penyebab kematian terbesar di dunia. salah satu contoh yang umum terjadi dengan jumlah penderita tertinggi adalah Diabetes Melitus (Soelistijo et al., 2015). Diabetes Melitus adalah suatu penyakit kronis yang terjadi ketika tubuh tidak mampu menghasilkan insulin (hormon yang mengatur gula darah atau glukosa) atau ketika tubuh tidak dapat secara efektif menggunakan insulin yang dihasilkan oleh tubuh (WHO, 2016). Diabetes melitus dapat menimbulkan beberapa komplikasi serius diantaranya hilangnya glukosa darah, dehidrasi, kerusakan jaringan, peningkatan pengunaan lemak, asidosis metabolik dan kehilangan protein (Guyton and Hall, 2014).

Obat-obat antidiabetes yang ada saat ini telah memberi kontrubusi besar dalam menurunkan diabetes melitus namun memiliki beberapa keterbatasan terutama efek samping (Novrial et al., 2012). Oleh karena itu salah satu metode alternatif yang dapat digunakan untuk mengatasi kadar gula darah adalah dengan penggunaan obat herbal yang merupakan metode alternatif berasal dari alam. Harapannya penggunaan obat herbal dapat meminimalkan kemungkinan terjadinya efek samping, tanaman herbal juga metode alternatif pengobatan yang efisien sehingga dapat dijangkau seluruh kalangan masyarakat. Salah satu pemanfaatan tumbuhan sebagai obat tradisional adalah tanaman putri malu (Mimosa pudica Linn).

Dalam penelitian yang dilakukan oleh Mustapa et al (2017) yaitu Pengaruh Ekstrak Tanaman Putri Malu (Mimosa Pudica Linn) Terhadap Penurunan Kadar Glukosa Darah Pada Mencit (Mus Musculus) menyatakan bahwa ekstrak tanaman putri malu 20\% sudah memberikan efek yang hampir sama dengan kontrol positif yaitu glibenklamid. Dalam penelitian yang telah dilakukan ditemukan kandungan alkaloid, tanin dan flavonoid. Keefektifan ekstrak tanaman putri malu dalam menurunkan kadar glukosa dalam darah dipengaruhi oleh ketiga senyawa ini. Sedangkan pada penelitian lain yang dilakukan oleh Prabawa (2015) ditemukan bahwa ekstrak etanol $70 \%$ akar dan batang putri malu (mimoasa pudica Linn) dengan dosis $600 \mathrm{mg} / \mathrm{kgbb}$ memiliki efek penurnan kadar glukosa dalam darah pada tikus putih jantan galur wistar yang diinduksi aloksan dengan dosis $600 \mathrm{mg} / \mathrm{kgbb}$. Tulisan ini dimaksudkan untuk memberikan gambaran pengaruh pemberian fraksi semipolar herba putri malu (mimosa pudica Linn) terhadap penurunan kadar glukosa darah pada mencit yang diinduksi aloksan.

\section{METODE PENELITIAN}

\section{Alat dan Bahan}

Alat yang digunakan adalah Gelas ukur, gelas kimia, labu ukur, 
corong, pisau/cutter, spatula, corong pisah, batang pengaduk, penangas listrik, spatula, lumpang dan alu, kain fanel, kapas, kertas label, kertas saring, pipet tetes, tabung reaksi, rak tabung, blender, glukometer, strip gluco, neraca digital, suntik sonde, gunting, sarung tangan, plat KLT (gel $\mathrm{F}_{254}$, GF 254), kandang hewan dan timbangan hewan. Bahan-bahan yang digunakan diantaranya Herba putri malu (mimosa pudica linn), Aloksan, Glibenklamid (Kimia Farma), Etanol $70 \%$, aquadest, $\mathrm{FeCl}_{2} 1 \%$, logam $\mathrm{Mg}$, $\mathrm{HCL}$, reagen dragendroff, asam asetat, $n$-butanol,etil asetat, asam formiat, Na CMC dan klorida, dan Mencit putih jantan (mus musculus).

\section{Cara Kerja}

\section{Pengumpulan dan Pengolahan} Simplisia Herba Putri Malu

Pengumpulan sampel dilakukan secara acak, sampel yang diambil berupa herba. Tanaman putri malu diambil dari lingkungan Jl. Jendral Sudirman, Karang Anyar, Pangkalan Bun, Kabupaten Kotawaringin Barat, Kalimantan Tengah. Simplisia segar yang telah dikumpulkan selanjutnya akan melalui beberapa tahapan yang terdiri dari sortasi basah, pencucian, penimbangan, perajangan, pengeringan, sortasi kering, dihaluskan dan penyimpanan.

\section{Pembuatan Ekstrak}

Ekstrak dibuat dengan metode maserasi menggunakan etanol $70 \%$. Herba putri malu yang sudah dalam bentuk serbuk dimasukkan kedalam maserator. Serbuk herba putri malu ditambahkan dengan etanol $70 \%$ dan didiamkan selama 3 hari sambil sesekali diaduk (setiap 6 jam). Setelah 3 hari filtrat disaring untuk memisahkan ampas dan filtrat.
Kemudian filtrat yang diperoleh dipekatkan menggunakan rotary evaporator pada suhu $40^{\circ} \mathrm{C}$ atau waterbath pada suhu $60^{\circ} \mathrm{C}$ sampai diperoleh ekstak kental.

\section{Uji Fitokimia Dengan Reagen}

\section{Senyawa Flavonoid}

Sampel sebanyak 0,5 gram ditimbang dan ditambahkan $5 \mathrm{ml}$ aquades kemudian dipanaskan lalu disaring. Filtrat ditambahkan 0,1 gram logam $\mathrm{Mg}$ dan 5 tetes $\mathrm{HCl}$ pekat. Jika menghasilkan warna kuning jingga maka senyawa positif mengandung flavonid.

2. Senyawa Alkaloid

Sampel sebanyak 0,5 gram ditimbang dan ditambahkan $5 \mathrm{ml}$ aquades kemudian dipanaskan dan disaring. Selanjutnya filtrat ditambahkan 5 tetes $\mathrm{HCl}$ pekat dan 5 tetes reagen Dragendorff. Jika menghasilkan endapan yang berwarna jingga maka positif mengandung alkaloid.

3. Senyawa Tanin

Sampel sebanyak 0,5 gram ditimbang dan ditambahkan $5 \mathrm{ml}$ aquades kemudian dipanaskan dan disaring. Selanjutnya filtrat ditambahkan 5 tetes $\mathrm{FeCl} 2$ 1\%. Jika terbentuk warna hijau kehitaman maka positif mengandung tanin.

\section{Pembuatan Fraksi}

Ekstrak kental herba putri malu difraksinasi dengan pelarut nonpolar, semipolar dan polar. Fraksinasi ekstrak dilakukan dengan metode ekstraksi cair-cair (ECC) menggunakan corong pisah. Ekstrak etanol herba putri malu ang telah dilarutkan air (polar) dimasukkan kedalam corong pisah dan difraksinasi dengan larutan n-heksana 
(nonpolar) dengan perbandingan 1:1, kemudian digojog selama \pm 15 menit. Setelah itu didiamkan hingga terbentuk dua lapisan yaitu lapisan ekstrak putri malu (polar) dan lapisan n-heksana (nonpolar). Lapisan nheksana dipisahkan dari lapisan air, kemudian proses diulangi hingga larutan jernih.

Selanjutnya lapisan polar difraksinasi dengan etil asetat (semipolar) dengan perbandingan 1:1, kemudian digojog selama \pm 15 menit, lalu didiamkan beberapa saat hingga terbentuk lapisan etil asetat dan lapisan air. Kemudian proses diulangi hingga larutan jernih. Lapisan etil asetat dipisahkan dengan lapisan air. Lapisan tersebut disebut sebagai fraksi etil asetat.

\section{Uji Fitokimia dengan Kromatografi Lapis Tipis}

Penyiapan fase diam berupa silica gel $\mathrm{G}_{60}, \mathrm{~F}_{254} /$ plat KLT dengan panjang $8 \mathrm{~cm}$ dan lebar $2 \mathrm{~cm}$, kemudian dicuci dengan metanol, lalu diaktivasi dengan oven pada suhu $100^{\circ} \mathrm{C}$ (10 menit). Sebanyak $10 \mathrm{mg}$ ekstrak dilarutkan dalam $1 \mathrm{ml}$ etanol lalu ditototlkan pada fase diam.

1. Senyewa Flavonoid

Ekstrak ditotolkan pada fase diam dan fase gerak yang digunakan adalah asam asetat glacial : butanol : air (1:4:5), dengan menggunakan penampak noda uap amoniak. Senyawa akan dikatakan positif mengandung senyawa flavonoid jika terbentuk warna kuning setelah diuapi dengan amoniak dan berwarna biru pada UV $366 \mathrm{~nm}$ yang menegaskan adanya kandungan flavonoid.

2. Senyawa Alkaloid

Ekstrak ditotolkan pada plat KLT dengan fase diam silika gel $\mathrm{F}_{254}$ dan fase gerak $n$-butanol : asam asetat : air (4:1:5) v/v dengan pereaksi semprot Dragendoff. Senyawa akan dikatakan positif mengandung senyawa alkaloid jika terdapat bercak berwarna merah coklat setelah disemprot dengan pereaksi Dragendorff.

3. Senyawa Tanin

Ekstrak ditotolkan pada fase diam dan fase gerak metanol - air (6:4) dengan menggunakan penampak noda pereaksi $\mathrm{FeCl}_{3}$ 5\%. Senyawa akan dikatakan positif mengandung tanin jika terbentuk noda berwana hitam.

\section{Persiapan Hewan Uji}

Mencit putih diperoleh dari luar kota Pangkalan Bun dan diadaptasikan selama 1 minggu dengan tempat, pakan dan minum yang disesuaikan. Mencit yang akan diuji adalah mencit jantan dengan berat 20-30 gram dan jumlah mencit yang digunakan dalam penelitian ini ialah sebanyak 18 ekor.

\section{Induksi Aloksan pada Hewan Uji}

Sebelum diberikan perlakukan, hewan uji terlebih dahulu dipuasakan selama 16 jam. Kemudian diukur kadar glukosa darahnya setelah itu semua hewan uji dikelompokkan dan diinduksi aloksan secara intraperitorial dengan dosis yang telah ditentukan. Pada hari ke 3 setelah pemberian induksi aloksan kadar glukosa darah hewan uji diukur kembali jika kadar glukosa darah > $120 \mathrm{mg} / \mathrm{dL}$ maka hewan uji telah mengalami hiperklikemia.

\section{Uji Pengaruh Antihiperglikemia}

Sebanyak 30 ekor hewan uji mencit jantan yang telah mengalami 
hiperglikemia dibagi menjadi 6 kelompok dengan perlakukan berbeda setiap kelompoknya, adapun perlakuan tersebut yaitu sebagai berikut; Kelompok I kontrol positif : Hewan uji diberi perlakuan 0,65 $\mathrm{mg} / \mathrm{kgBB} /$ hari larutan glibenklamid 5 mg, Kelompok II kontrol negatif : Hewan uji diberi perlakuan larutan $\mathrm{Na}$ CMC 0,05\%, Kelompok III kelompok perlakuan I : Hewan uji diberi perlakuan ekstrak herba putri malu (mimosa pudica linn) dosis 2,5 $\mathrm{gr} / \mathrm{kgBB}$, Kelompok IV kelompok perlakuan II : Hewan uji diberi perlakuan ekstrak herba putri malu (mimosa pudica linn) dosis 5 $\mathrm{gr} / \mathrm{kgBB}$, Kelompok V kelompok perlakuan III : Hewan uji diberi fraksi semi polar herba putri malu (mimosa pudica linn) dosis $0,7 \mathrm{gr} / \mathrm{kgBB}$, Kelompok VI kelompok perlakuan IV : Hewan uji diberi fraksi semi polar herba putri malu (mimosa pudica linn) dosis $1,3 \mathrm{gr} / \mathrm{kgBB}$.

\section{Pengukuran Kadar Glukosa Darah Hewan Uji}

Sebelum digunakan, glukometer dihidupkan dengan strip glukosa dimasukkan ke dalam glukometer. Kemudian darah diambil melalui ekor hewan uji (mencit) kemudian diteteskan pada strip glukometer. Dalam waktu 10 detik kadar glukosa darah akan terukur secara otomatis dan hasilnya dapat dibaca dari monitor glukometer.

\section{Analisis Data}

Setelah hasil data glukosa darah awal diperoleh meliputi glukosa darah setelah induksi, glukosa darah setelah perlakuan dan penurunan glukosa dari kelima kelompok perlakuan tersebut kemudian dilanjutkan dengan analisis dan dievaluasi dengan menggunakan rancangan acak kelompok melalui uji statistik analisi sidik ragam (uji F) atau Uji Anova dengan taraf kepercayaan 95\%. Pengujian ini digunakan untuk mengetahui perbedaan yang signifikan dari semua perlakuan.

Setelah uji Anova selesai dilanjutkan dengan uji LSD (Least Significant Difference). Uji ini dilakukan untuk mengetahui pada perlakuan mana yang memiliki perbedaan yang bermakna dalam menentukan konsentrasi yang paling efektif dalam menurunkan kadar glukosa darah pada mencit yang telah diinduksi aloksan.

\section{HASIL DAN PEMBAHASAN}

\section{Uji Fitokimia Menggunakan Reagen dan Uji Fitokimia dengan Kromatografi Lapis Tipis}

Hasil Uji Fitokimia Ekstrak Putri Malu (Mimosa Pudica Linn) Menggunakan Reagen Dapat Dilihat Pada Tabel 1. Sedangkan Hasil Uji Fitokimia Ekstrak Putri Malu (Mimosa Pudica Linn) Menggunakan Kromatografi Lapis Tipis Dapat Dilihat Pada Tabel 2.

Dari hasil uji fitokimia ekstrak putri malu (Mimosa Pudica Linn) menggunakan reagen pada Tabel 1 dapat diketahui bahwa ekstrak tanaman putri malu positif mengandung senyawa Flavonoid, alkaloid dan tanin.

Tabel 1. Hasil Uji Fitokimia Ekstrak Herba Putri Malu (Mimosa Pudica Linn)

\begin{tabular}{ccc}
\hline Perlakuan & Hasil & Kesimpulan \\
\hline
\end{tabular}




\begin{tabular}{|c|c|c|}
\hline 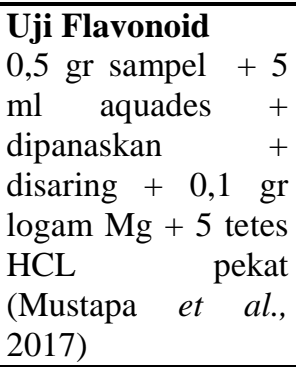 & $\begin{array}{c}\text { Berwarn } \\
\text { a kuning } \\
\text { jingga }\end{array}$ & $(+)$ \\
\hline $\begin{array}{l}\text { Uji Alkaloid } \\
0,5 \text { gr sampel }+5 \\
\text { ml aquades }+ \\
\text { dipanaskan }+ \\
\text { disaring }+5 \text { tetes } \\
\text { HCL pekat }+5 \text { tetes } \\
\text { reagen dragendroff } \\
\text { (Mustapa et al., } \\
2017)\end{array}$ & $\begin{array}{c}\text { Endapan } \\
\text { kuning } \\
\text { jingga }\end{array}$ & $(+)$ \\
\hline $\begin{array}{l}\text { Uji Tanin } \\
0,5 \text { gr sampel }+5 \\
\text { ml aquades }+ \\
\text { dipanaskan } \\
\text { disaring }+5 \text { tetes } \\
\text { FeCl3 } 1 \% \\
\text { (Mustapa et al., } \\
\text { 2017) }\end{array}$ & $\begin{array}{c}\text { Hijau } \\
\text { kehitama } \\
\text { n }\end{array}$ & $(+)$ \\
\hline
\end{tabular}

Sedangkan uji fitokimia ekstrak putri malu (Mimosa Pudica Linn) menggunkan kromatografi lapis tipis pada Tabel 2 juga diketahui bahwa ekstrak tanaman putri malu positif mengandung senyawa Flavonoid, alkaloid dan tanin.

Peran flavonoid dalam menurunkan kadar glukoda darah puasa diantaranya bekerja sebagai anti radikal bebeas dengan cara menangkap radikal bebas (ROS/Reactive Oxygen Species atau RNS/Reactive Nitrogen Species) melalui transfer elektron serta menghambat reaksi peroksidasi. Selain itu flavonoid juga bekerja langsung pada sel beta pankreas dengan cara memicu pengaktifan kaskade sinyal cAMP yang dapat memperkuat seksresi insulin (Hikmah dan Khildah, 2016).
Flavonoid terbukti mampu merangsang sistem kekebalan tubuh karena memiliki karakter antioksidan yang dapat memulihkan kerusakan sel beta pankreas oleh aloksan (Mustapa et al., 2017).

Tabel 2. Hasil Uji Kromatografi Lapis Tipis (KLT) Ekstrak Herba Putri Malu (Mimosa Pudica Linn)

\begin{tabular}{lll}
\hline \multicolumn{1}{c}{ Perlakuan } & Hasil & Kesimpulan \\
\hline $\begin{array}{l}\text { Uji Flavonoid } \\
\text { fase gerak asetat }\end{array}$ & & \\
glacial : butanol : & kuning & \\
air (1:4:5), & (kuning & $(+)$ \\
penampak noda & pudar) & \\
uap amoniak & & \\
(Marliana, 2005) & & \\
\hline
\end{tabular}

$\begin{array}{ll}\text { Uji Alkaloid } & \\ \text { fase gerak } n & \\ \text { butanol : asam } & \\ \text { asetat : air } & \text { warna } \\ \text { (4:1:5),pereaksi } & \text { coklat } \\ \text { dragendoff } & \text { pudar } \\ \text { (Widyaningsih } \text { et } & \\ \text { al., 2016) } & \end{array}$

\begin{tabular}{|c|}
\hline $\begin{array}{l}\text { Uji Tanin } \\
\text { fase gerak } \\
\text { metanol : air } \\
\text { (6:4),pereaksi } \\
\text { FeC13 5\%. (Banu } \\
\text { dan Nagarajan, } \\
\text { 2014) } \\
\end{array}$ \\
\hline 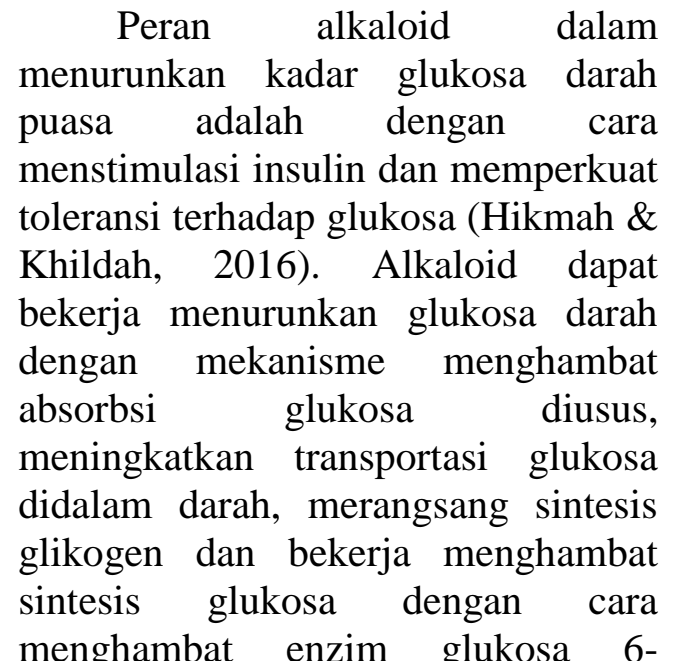 \\
\hline
\end{tabular}


fosfatase, fruktosa 1,6-bifosfatase, serta dapat meningkatkan oksidasi glukosa melalui glukosa 6fosfatdehidrogenase. Alkaloid juga mempunyai kemampuan regenerasi sel beta pankreas yang telah rusak (Mustapa et al., 2017).

Sedangkan peran tanin dalam dalam menurunkan kadar glukosa darah puasa hampir mirip dengan flavonoid dimana tanin bekerja menangkap radikal bebas dan mengurangi peningkatan stress oksidatif (Hikmah \& Khildah, 2016). Mekanisme tanin diketahui dapat memacu metabolisme glukosa dan lemak sehingga timbunan kedua sumber kalori tersebut dalam darah dapat dihindari. Selain itu, tanin juga berfungsi sebagai astringent atau pengkhelat yang dapat memperkecil membran epitel usus halus sehingga dapat mengurangi penyerapan sari makanan dan sebagai akibatnya menghambat asupan gula dan laju peningkatan gula darah tidak terlalu tinggi (Mustapa et al., 2017).

\section{Pengaruh Pemberian Fraksi Semipolar Herba Putri Malu (Mimosa Pudica Linn) Terhadap Penurunan Kadar Glukosa Darah Pada Mencit Yang Diinduksi Aloksan}

Fraksi semipolar herba putri malu (mimosa pudica linn) dalam penelitian ini diberikan pada mencit jantan dengan berat 20-30 gram. Sebelum dimulai penelitian uji pengaruh mencit terlebih dahulu diadaptasikan selama 7 hari untuk menyesuaikan diri dengan lingkungannya selama penelitan

Tabel 3. Rerata Peningkatan Dan Penurunan Kadar GDP (Mg/dl) Hewan Uji Pada Semua Kelompok Perlakuan

\begin{tabular}{|c|c|c|c|c|}
\hline Kelompok & $\begin{array}{c}\text { GDP har } \\
\text { ke- } 0\end{array}$ & $\begin{array}{c}\text { GDP ha } \\
\text { ke-3 }\end{array}$ & $\begin{array}{r}\% \\
\text { Kenai }\end{array}$ & \\
\hline
\end{tabular}

berlangsung (Hikmah \& Khildah, 2016). Setelah dipuasakan, mencit tersebut diukur kadar glukosa darah awalnya dengan menggunakan glukometer yang menunjukkan hasil normal yaitu sebesar $78,8 \mathrm{mg} / \mathrm{dL}$ dan nilai standar deviasi 17,37.

Setelah dapat nilai normal maka proses dilanjutkan dengan induksi aloksan selama 3 hari. Pemilihan aloksan sebagai agen penginduksi karena mampu membuat kondisi diabetes pada hewan uji dalam waktu cukup singkat yaitu 2-3 hari setelah induksi (Hikmah \& Khildah, 2016). Pengukuran glukosa darah puasa dilakukan kembali setelah 3 hari untuk memastikan bahwa mencit telah mengalami hiperglikemia dan sebelum pengukuran hewan mencit terlebih dahulu dipuasakan. Hasil kadar GDP hewan uji pada penelitian diketahui sebesar 157,3 mg/dL $(n=18)$ dengan nilai standar deviasi 14,46 . Jika kadar gula darah puasa mencit > $120 \mathrm{mg} / \mathrm{dL}$ maka hewan uji telah mengalami hiperglikemia.

Mencit yang telah dalam keadaan hiperglikemia setelah diinduksi aloksan selanjutnya diberi perlakuan sesuai kelompok uji selama 14 hari. Hasil rerata kadar glukosa darah awal, setelah induksi, setelah diberikan perlakuaan dan penurunan kadar glukosa darah setelah diberikan fraksi semipolar herba putri malu (mimosa pudica linn) dapat dilihat pada Tabel 3.

Untuk mengetahui seberapa besar penurunan kadar glukosa darah pada mencit maka dilakukan perhitungan selisih antara kadar 


\begin{tabular}{|c|c|c|c|c|c|c|c|}
\hline & $\mathrm{X} \pm \mathrm{SD}$ & $\mathrm{X} \pm \mathrm{SD}$ & $\mathrm{X} \pm \mathrm{SD}$ & $\mathrm{X} \pm \mathrm{SD}$ & $\mathrm{X} \pm \mathrm{SD}$ & $\mathrm{X} \pm \mathrm{SD}$ & $\mathrm{X} \pm \mathrm{SD}$ \\
\hline $\begin{array}{l}\text { Kontrol Positif } \\
\text { Glibenklamid }\end{array}$ & $\begin{array}{c}82,3 \pm \\
11,15\end{array}$ & $\begin{array}{c}148 \pm \\
5,56\end{array}$ & $82 \pm 29,5$ & $\begin{array}{l}113 \pm \\
11,26\end{array}$ & $\begin{array}{c}105,6 \\
\pm 12,58\end{array}$ & $\begin{array}{c}93,6 \pm \\
6,65\end{array}$ & $37 \pm 6,5^{*}$ \\
\hline $\begin{array}{l}\text { Kontrol Negatif } \\
\mathrm{NaCMC}\end{array}$ & $\begin{array}{c}96,9 \pm \\
16,6\end{array}$ & $\begin{array}{c}166,3 \pm \\
12,74\end{array}$ & $\begin{array}{l}75 \pm \\
24,2\end{array}$ & $\begin{array}{c}180,6 \pm \\
17,38\end{array}$ & $\begin{array}{l}186 \pm \\
18,19\end{array}$ & $\begin{array}{c}186,6 \pm \\
18,82\end{array}$ & $-12 \pm 11,9$ \\
\hline $\begin{array}{l}\text { Perlakuan I } \\
\text { Ekstrak 2,5 } \\
\text { gr/kgBB }\end{array}$ & $86 \pm 4$ & $\begin{array}{c}159,3 \pm \\
24,0\end{array}$ & $\begin{array}{l}85 \pm \\
28,3\end{array}$ & $\begin{array}{c}143,3 \pm \\
33,3\end{array}$ & $\begin{array}{c}119,6 \pm \\
10,9\end{array}$ & $\begin{array}{c}105,3 \pm \\
7,02\end{array}$ & $33 \pm 9,7 * *$ \\
\hline $\begin{array}{l}\text { Perlakuan II } \\
\text { Ekstrak } 5 \\
\text { gr/kgBB }\end{array}$ & $\begin{array}{c}65,3 \pm \\
9,29\end{array}$ & $\begin{array}{c}161,6 \pm \\
15,56\end{array}$ & $\begin{array}{c}149 \pm \\
26,3\end{array}$ & $\begin{array}{c}144,3 \pm \\
10,0\end{array}$ & $\begin{array}{c}126,3 \pm \\
10,0\end{array}$ & $\begin{array}{c}105,6 \pm \\
5,50\end{array}$ & $34 \pm 6,8 * *$ \\
\hline $\begin{array}{l}\text { Perlakuan III } \\
\text { Fraksi } 0,7 \\
\text { gr/kgBB } \\
\end{array}$ & $\begin{array}{c}73 \pm \\
22,51\end{array}$ & $\begin{array}{c}159,6 \pm \\
18,5\end{array}$ & $\begin{array}{l}131 \pm \\
6,76\end{array}$ & $\begin{array}{l}141 \pm \\
19,28\end{array}$ & $\begin{array}{c}122,6 \pm \\
7,76\end{array}$ & $\begin{array}{c}102 \\
6 \pm 8,38\end{array}$ & $35 \pm 5,60 * *$ \\
\hline $\begin{array}{l}\text { Perlakuan IV } \\
\text { Fraksi } 1,3 \\
\text { gr/kgBB }\end{array}$ & $\begin{array}{l}70 \pm \\
23,2\end{array}$ & $\begin{array}{c}149 \pm \\
5\end{array}$ & $\begin{array}{c}128 \pm \\
68,6\end{array}$ & $\begin{array}{c}135 \pm \\
5,29\end{array}$ & $\begin{array}{c}107 \pm \\
7\end{array}$ & $\begin{array}{l}97 \pm \\
2,64\end{array}$ & $36 \pm 1,1 * *$ \\
\hline
\end{tabular}

Keterangan

* $\quad=$ Kontrol Positif berbeda secara signifikan dengan Kontrol negatif

** $\quad=$ Kelompok perlakukan berbeda secara signifikan dengan Kontrol negatif

glukosa darah setelah induksi dengan kadar glukosa darah setelah pemberian fraksi semipolar herba putri malu (mimosa pudica linn). Hasil penurunan kadar glukosa darah dapat diketahui melalui perhitungan dari kadar glukosa darah setelah diinduksi dikurangi dengan kadar glukosa darah setelah perlakuan. Kemudian dihitung reratanya seperti yang tertera pada Tabel 3. Adapun grafik penurunan kadar glukosa darah pada mencit terlihat pada Gambar 1.

Jika dilihat dari grafik penurunan kadar gula darah terdapat perbedaan secara signifikan antara hari ke-3 setelah induksi dan hari ke18 setelah perlakuan 2 minggu. Dimana ada penurunan secara signifikan dari pemberian fraksi semi polar herba putri malu terhadap kadar

Kontrol positif menunjukkan penurunan sebesar $37 \%$. Penurunan kadar gula darah ini ada kaitannya dengan zat aktif dari obat glibenklamid yang diberikan pada glukosa darah mencit yang diinduksi aloksan. Perlakuan yang paling berbeda nyata adalah kontrol positif dan kelompok perlakuan IV.

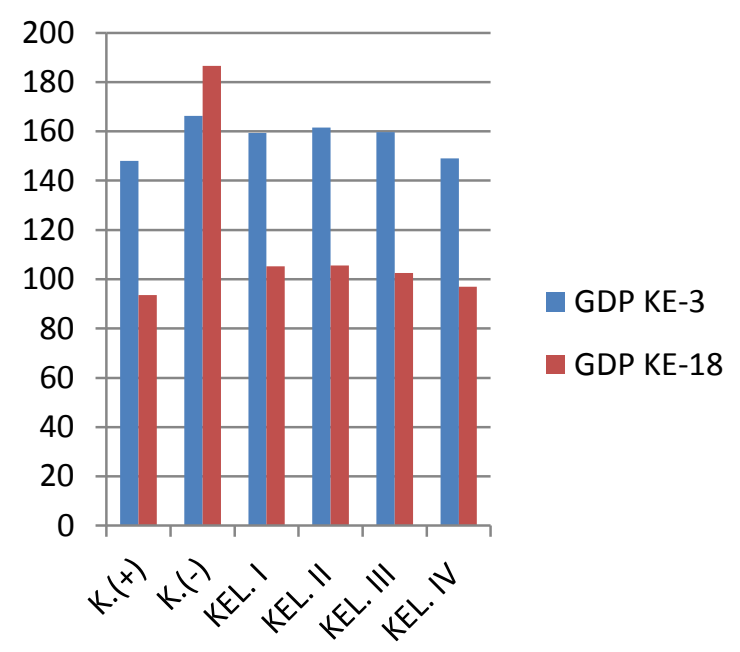

Gambar 1. Grafik Penurunan Kadar Glukosa Darah

kelompok tersebut. Penurunan terjadi karena glibenklamid bekerja dengan cara merangsang pelepasan insulin endogen dari sel beta pankreas. Glibenklamid juga sepenuhnya cepat 
diserap oleh saluran pencernaan dan memiliki efek antidiabetes yang paling kuat dan tahan lama (Feldman JM, 1985).

Sedangkan pada kelompok perlakuan IV menunjukkan penurunan sebesar 36\%. Kelompok perlakuan IV ialah kelompok perlakuan yang bekerja paling baik setelah kontrol positif.

Persentase penurunan kadar GDP selanjutnya dianalisa dengan program statistika. Hasil analisa menunjukkan data berdistribusi normal dan memiliki homogenitas yang baik $(p>0,05)$. Dilanjutkan uji ANOVA untuk mengetahui perbedaan kadar gula darah setiap kelompok perlakuan.

Tabel 4. Hasil uji ANOVA penurunan kadar glukosa darah

\begin{tabular}{lccccc}
\hline & $\begin{array}{c}\text { Sum if } \\
\text { squares }\end{array}$ & of & $\begin{array}{c}\text { Mean } \\
\text { Square }\end{array}$ & f & sig \\
\hline $\begin{array}{l}\text { Betwee } \\
\text { Groups } \\
\text { Within } \\
\text { Groups }\end{array}$ & 5641,833 & 5 & 1128,367 & 20,070 &, 000 \\
& 647,667 & 12 & 56,222 & & \\
Total & 6316,500 & 17 & & & \\
\hline
\end{tabular}

Pada Tabel 4 Hasil uji ANOVA menunjukkan perbedaan secara signifikan pada setiap kelompok yang ditunjukkan dengan hasil sig 0,000 $(p<0,05)$. Kemudian untuk hasil ANOVA terhadap persen penurunan kadar GDP menunjukkan $\mathrm{F}$ hitung $(20,070)>F$ tabel $(3,11)$. Sehingga hal tersebut menyatakan bahwa $\mathrm{H}_{0}$ ditolak dan $\mathrm{H}_{1}$ diterima yang artinya terdapat pengaruh pemberian fraksi semi polar herba putri malu (mimosa pudica Linn) terhadap penurunan kadar glukosa darah pada mencit yang diinduksi aloksan.

Setelah uji ANOVA dilanjutkan uji LSD (Least Significant Difference) untuk mengetahui pada perlakuan mana yang memiliki perbedaan yang bermakna dalam menentukan konsentrasi yang paling efektif dalam menurunkan kadar glukosa darah pada mencit yang telah diinduksi aloksan.

Tabel 5. Hasil Uji LSD Penurunan Kadar glukosa Darah

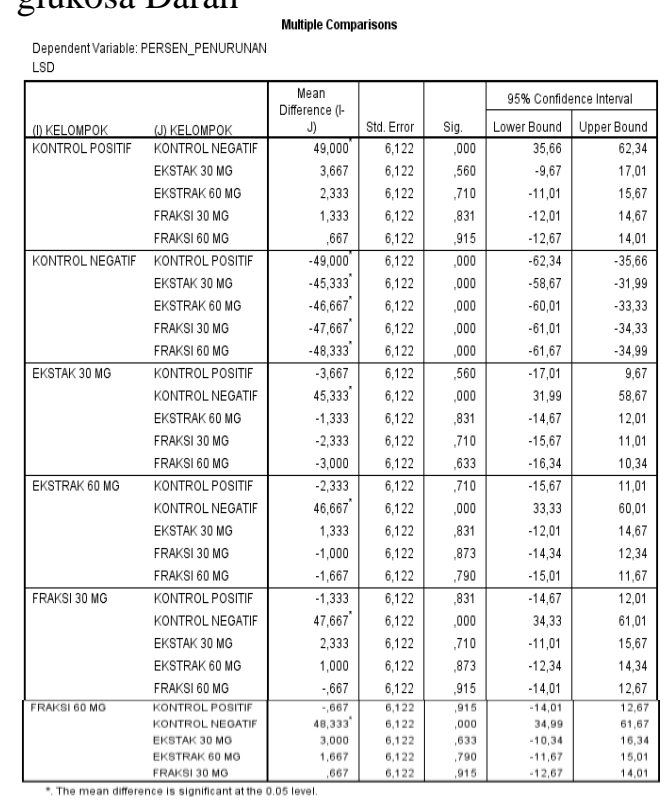

Pada Tabel 5 hasil uji LSD menunjukkan pemberian Fraksi semipolar herba putri malu (Perlakuan IV) dan pemberian Glibenklamid (Kontrol Positif) menunjukkan perbedaan nyata jika dibandingkan dengan kelompok perlakuan lain. Pada pemberian perlakuan I, II, \& III menunjukkan perbedaan secara signifikan dengan kontrol negatif dan tidak menunjukkan perbedaan secara signifikan dengan kontrol positif yaitu glibenklamid. Namun diantara ke empat perlakuan, perlakuan IV yaitu Fraksi semipolar herba putri malu dengan dosis $1,3 \mathrm{gr} / \mathrm{kgBB}$ yang justru memiliki kemampuan paling baik diantara kelompok perlakuan I, II, \& 
III. Penurunan kadar glukosa darah pada kelompok perlakuan Fraksi semi polar herba putri malu ada kaitannya dengan kandungan senyawa metabolit sekunder yang terdapat pada herba putri malu. Kandungan metabolit sekunder tersebut terdiri dari alkaloid, flavonoid dan tanin.

\section{KESIMPULAN DAN SARAN}

Pemberian fraksi semi polar herba putri malu (mimosa pudica linn) berpengaruh terhadap penurunan kadar glukosa darah pada mencit yang diinduksi aloksan. Dimana Pemberian kelompok perlakuan IV (fraksi dosis 1,3 gr/kgBB) memiliki kemampuan paling baik diantara kelompok perlakuan lain (I,II, \& III).

Saran yang dapat diambil dari artikel ini adalah sebagai berikut.

1. Perlu dilakukan penelitian lanjutan menggunakan Fraksi semi polar herba putri malu mengenai toksisitas obat, efek samping yang mungkin ditimbulkan, dan lain sebagainya.

2. Dapat dilakukan penelitian lanjutan mengenai efek pengaruh fraksi polar herba putri malu ataupun bentuk sediaan lainnya dalam menurunkan kadar glukosa darah pada mencit yang diinduksi aloksan.

\section{DAFTAR PUSTAKA}

Banu, R. H., Nagarajan, N. 2014. TLC and HPTLC fingerprinting of leaf extracts of Wedelia Chinensis(Osbeck) Merrill. Jurnal of Pharmacognosy and Phytochemistry. 2(6) pp 29-33.

Feldman, J.M. 1985. Review of glyburide after one year on the market. Amer. J. Med. 79,
Suppl.3B

Guyton, A. C., Hall, J. E. 2014. Buku Ajar Fisiologi Kedokteran. Edisi 12. Jakarta : EGC.

Hikmah, N. Y. dan Khildah K. 2016. Pengaruh Pemberian Ekstrak Daun Salam (Syzygium Polyanthum Wight.) Terhadap Glibenklamid Dalam Menurunkan Kadar Glukosa Darah Mencit(Mus Musculus) Yang Diinduksi Aloksan. Jurusan Farmasi, Fakultas MIPA,Universitas Tadulako, Palu, Indonesia. Vol. 2 (1) : 24 30. ISSN : 2442-8744.

Mustapa, K., Rizky, A., dan Jura, M. R. 2017. Pengaruh Ekstrak Tanaman Putri Malu ( Mimosa Pudica Linn ) Terhadap Penurunan Kadar Glukosa Darah Pada Mencit ( Mus Musculus) The Effect Of Mimosa Plant Extract ( Mimosa Pudica Linn ) On Decreasing Of Blood Sugar Levels On Mice ( Mus Musculus ), 6 (1), 7-14.

Marliana, S.D. 1988. Cara Mengidentifiasi Flavonoid. Terjemahan oleh Kosasih Padmawinata, ITB, Bandung.

Novrial, D., Sulistio, H., dan Setiawati. 2012. Perbandingan efek antidiabetik madu,glibenklamid, metformin dan kombinasi pada tikus yang diinduksi streptozotocin. Prosiding Seminar Nasional Kesehatan Jurusan Kesehatan Masyarakat FKIK UNSOED.

Prabawa, M. D. K. 2015. Uji Efek Penurun Glukosa Darah Ekstrak Etanol 70\% Akar Dan Batang Putri Malu (Mimosa Pudica) Pada Tikus Putih Jantan Galur Wistar Yang Diinduksi Aloksan. Universitas 
Muhammadiyah Surakarta.

Soelistijo, S., Novida, H., Rudijanto, A., Soewondo, P., Suastika, K., Manaf, A., dan Soetedjo, N. 2015. Konsesus Pengelolaan Dan

Pencegahan Diabetes Melitus

Tipe2 Di Indonesia 2015.

Perkeni.

WHO. 2016. Global Report on Diabetes. World Health Organization

Widyaningsih, W., Pramono, S., dan

Widyarini, S. 2016. Skrining

Fitokimia Ekstrak Etanol Ulva

Lactuca L. Dengan Metode

Kromatografi Lapis Tipis. Media

Farmasi: Jurnal Ilmu Farmasi, 13

(2), 199-211.

http://doi.org/10.12928/mf.v13i2.

7772 
